\section{Nitrogen Rate and Application Timing Affect 'Beauregard' Sweetpotato Yield and Quality}

\author{
S.B. Phillips ${ }^{1}$ and J.G. Warren \\ Eastern Shore Agricultural Research and Extension Center, 33446 Research \\ Drive, Virginia Polytechnic Institute and State University, Painter, VA 23420
}

G.L. Mullins

Department of Crop and Soil Environmental Sciences, 424 Smyth Hall (0403), Virginia Polytechnic Institute and State University, Blacksburg, VA 24061

Additional index words. Ipomoea batatas, fertilizer, $\mathrm{N}$ use efficiency, crude protein

\begin{abstract}
Previous work suggests that 'Beauregard' sweetpotato [Ipomoea batatas (L.) Lam.] has a much lower $\mathrm{N}$ requirement than other common cultivars. Over the past 10 years, 'Beauregard' has become the premier sweetpotato cultivar grown in Virginia; however, $\mathbf{N}$ fertilizer recommendations have not been reassessed to consider the potentially lower $\mathrm{N}$ requirement of 'Beauregard'. The objectives of this study were to evaluate the effects of $\mathrm{N}$ rate and application timing on root yield, quality, and $\mathrm{N}$ use efficiency for 'Beauregard' sweetpotato production in Virginia. A field study was conducted each year from 2000 to 2002 at the Eastern Shore Agricultural Research and Extension Center, Painter, Va. Nitrogen fertilizer was applied at rates of 28, 56, and $84 \mathrm{~kg}^{-h^{-1}}$ either before transplanting, 2 to 3 weeks after transplanting (WAT), or 4 to 5 WAT. A check treatment that received no $\mathbf{N}$ fertilizer was also included. Optimum $N$ rates varied annually; under normal precipitation, root yield was greatest at the $28-\mathrm{kg} \cdot \mathrm{ha}^{-1}$ rate, while $56 \mathrm{~kg} \cdot \mathrm{ha}^{-1}$ was required for maximum yield in wet conditions. Of note is that this range of rates is considerably lower than the current $\mathrm{N}$ recommendation for Virginia sweetpotato production (56 to $84 \mathrm{~kg} \cdot \mathrm{ha}^{-1}$ ). Delaying $\mathrm{N}$ application until 2 to 3 WAT further increased marketable root yield compared with applying $\mathbf{N}$ before transplanting or 4 to 5 WAT. Crude protein and $N$ uptake increased with increasing $N$ rate up to $84 \mathrm{~kg} \cdot \mathrm{ha}^{-1}$; however, $\mathrm{N}$ use efficiency was highest $(67 \%)$ when $28 \mathrm{~kg}^{\circ} \mathrm{h}^{-1}$ was applied 2 to 3 WAT.
\end{abstract}

Optimizing $\mathrm{N}$ fertilizer applications is critical for commercial sweetpotato [Ipomoea batatas (L.)Lam.] production. While somelevel of $\mathrm{N}$ fertilization is almost always necessary to obtain optimum root yield (Walker and Woodson, 1987) and protein concentration (Purcell et al., 1982), excessive $\mathrm{N}$ can reduce yield (Villagarcia et al., 1998). Extreme moisture at high $\mathrm{N}$ fertility levels has also resulted in decreased root yield and quality (Constantin et al., 1974). Variations in soil and climatic characteristics and genotypic differences in Nuptake and utilization efficiencies make identifying this optimum $\mathrm{N}$ balance extremely complicated.

Sweetpotato yield responses to $\mathrm{N}$ applications vary considerably and are often inconsistent or contradictory (Bellinder and Morse, 1982; Mascianica, et al., 1985). Large field-tofield differences in crude protein content and other quality factors of sweetpotato also exist (Purcell et al., 1978; Constantin et al., 1984). The difficulty in determining optimum $\mathrm{N}$ rates for sweetpotato production often results in low $\mathrm{N}$ use efficiency (NUE; percentage of applied N removed in the harvested portion of the crop), which can lead to excess fertilizer $\mathrm{N}$ remaining in the environment and having the potential to

Received for publication 9 Oct. 2003. Accepted for publication 28 june 2004. We thank the Virginia Sweetpotato Board for the financial support necessary to conduct this work.

${ }^{1}$ To whom reprint requests should be addressed; e-mailstevep@vt.edu. the Louisiana Agricultural Experiment Station in 1987 (Rolston et al., 1987).

'Beauregard' is one of the predominant sweetpotato cultivars grown in the mid-Atlantic U.S. In North Carolina, which is ranked number one in sweetpotato production (Virginia Agricultural Statistics Service, 2002), acreage planted to 'Beauregard' has increased steadily over the past 10 years (Schultheis et al., 1999), while nearly $100 \%$ of the orange-flesh acreage in Virginia is planted to 'Beauregard' (S.B. Sterrett, personal communication). Research from North Carolina suggests that 'Beauregard' has a much lower $\mathrm{N}$ requirement than other common cultivars (Peet, 2003) and that lower $\mathrm{N}$ application rates can be used for commercial production of 'Beauregard' $\left(56 \mathrm{~kg} \cdot \mathrm{ha}^{-1}\right.$ compared with 90 to $108 \mathrm{~kg} \cdot \mathrm{ha}^{-1}$; Jester, 1995). These lower $\mathrm{N}$ rates can be applied without a reduction in root yield (Jester, 1995), which would result in higher NUE for 'Beauregard' compared with other cultivars. In the North Carolina studies, $\mathrm{N}$ at $56 \mathrm{~kg} \cdot \mathrm{ha}^{-1}$ was adequate for optimum yield even in years with excessive rainfall, suggesting that the optimum $\mathrm{N}$ rate for 'Beauregard' production might actually be lower; however, $\mathrm{N}$ application rates below 56 $\mathrm{kg} \cdot \mathrm{ha}^{-1}$ were not evaluated. Cultural practice guidelines for the mid-Atlantic region also indicate that 'Beauregard' stand establishment is more uniform and the total marketable yield is highest when $\mathrm{N}$ applications are delayed 3 to 5 weeks after transplanting (Jester, 1995; Tuckey, 2001).

Current Virginia recommendations suggest applying $\mathrm{N}$ at $28 \mathrm{~kg} \cdot \mathrm{ha}^{-1}$ at transplanting and another 28 to $56 \mathrm{~kg} \cdot \mathrm{ha}^{-1}$ when vines begin to proliferate (about 4 to 5 weeks after transplanting) (Alexander et al., 2003). No adjustments have been made to the recommendations since 'Beauregard' has become the premier cultivar in Virginia.Personal communication with Virginia sweetpotato growers indicates that most are still applying $\mathrm{N}$ at rates of approximately 56 to 67 $\mathrm{kg} \cdot \mathrm{ha}^{-1}$. It is not unreasonable to assume that optimum N fertilizer strategies for 'Beauregard' sweetpotato production in Virginia would be similar to those in North Carolina and that the current $\mathrm{N}$ fertilizer recommendations in Virginia may need to be reassessed. Therefore, the objectives of this study were to 1)identify the optimum $\mathrm{N}$ rate and time of application for 'Beauregard' sweetpotato production in Virginia and 2) determine the effect of $\mathrm{N}$ rate and timing on root quality characteristics and NUE.

\section{Materials and Methods}

A field experiment was conducted each year from 2000 to 2002 at the Eastern Shore 
Table 2. Cultural practice dates for 'Beauregard' sweetpotato N management study, Painter, Va., 2000 through 2002; numbers in parenthesis indicate days after transplanting.

\begin{tabular}{lcccc}
\hline Year & Transplanted & 2 to 3 WAT & 4 to 5 WAT & Harvested \\
\hline 2000 & 16 June & 10 July (24) & 25 July (39) & 16 Oct (115) \\
2001 & 20 June & 10 July (20) & 23 July (33) & 17 Oct (119) \\
2002 & 5 June & 24 June (19) & 8 July (33) & 2 Oct (119) \\
\hline
\end{tabular}

${ }^{2} \mathrm{WAT}=$ weeks after transplanting; sidedress fertilizer application dates.
Agricultural Research and Extension Center, Painter, Va., on a Bojac sandy loam (mixed, thermic Typic Hapludult). Annual growing season rainfall at the site is reported in Table 1. The experimental design was a randomized complete block with four replications. Plot size consisted of four 7.6-m rows with $0.9 \mathrm{~m}$ between rows and $30.5-\mathrm{cm}$ plant spacing. Nitrogen fertilizer treatments consisted of three rates $\left(28,56\right.$, and $\left.84 \mathrm{~kg} \cdot \mathrm{ha}^{-1}\right)$ applied as ammonium nitrate (34-0-0) either before transplanting, 2 to 3 weeks after transplanting (WAT), or 4 to 5 WAT (Table 2). A $56-\mathrm{kg} \cdot \mathrm{ha}^{-1}$ rate was also split-applied using two $28-\mathrm{kg} \cdot \mathrm{ha}^{-1}$ increments applied either before transplanting and 2 to 3 WAT, before transplanting and 4 to 5 WAT, or 2 to 3 WAT and 4 to 5 WAT. A check plot that received no $\mathrm{N}$ fertilizer was also included. Additional nutrients applied each year to the experimental areaincluded $\mathrm{P}_{2} \mathrm{O}_{5}$ at $56 \mathrm{~kg} \cdot \mathrm{ha}^{-1}$ and $\mathrm{K}_{2} \mathrm{O}$ at $112 \mathrm{~kg} \cdot \mathrm{ha}^{-1}$ as triple superphosphate $(0-46-0)$ and potassium chloride $(0-0-60)$, respectively. All fertilizer sources were broadcast-applied using a ground-driven, drop-type dry fertilizer spreader and incorporated into the upper $15 \mathrm{~cm}$ of soil.

Sweetpotato plants were established in early April each year in 39.4- $\mathrm{m}^{2}$ plastic-covered, sand-filled, raised, wooden beds. Before planting, $4.5 \mathrm{~kg}$ of commercial fertilizer (10-10-10) was incorporated into each bed. About $68 \mathrm{~kg}$ 'Beauregard' seed was planted into each bed and watered as needed until field plot establishment. In June of each year, sprouts were pulled from the beds and transplanted into the plots using a 1-row mechanical transplanter (Table 2 ). Pesticides, cultivation, and irrigation were administered as needed throughout the duration of the study. Table 2), roots were mechanically dug from the center two rows of each plot and collected by hand. Plot weight was recorded for yield determination. Harvested roots were graded according to USDA standards (U.S. Dept. of Agriculture, 1981), which included canner roots (diameter of $2.5 \leq 4.4 \mathrm{~cm}$ ), US \#1 roots (diameter of $4.4 \leq 8.9 \mathrm{~cm})$, jumbo roots (diameter $>8.9 \mathrm{~cm}$ ), and cull roots (malformed or distorted roots). In 2000 and 2001, a subsample of US \#1 grade roots was collected from each plot for determination of moisture and total $\mathrm{N}$ content. Subsamples were sliced horizontally, dried at $60{ }^{\circ} \mathrm{C}$, and ground to pass a $150-\mu \mathrm{m}$ sieve. Total $\mathrm{N}$ was determined using a $\mathrm{CE}$ Elantech NC 2100 automated dry combustion analyzer. Crude protein content was estimated by multiplying total $\mathrm{N}$ by 6.25 (Purcell et al., 1982). Nitrogen use efficiency for this study was calculated as [ $\mathrm{N}$ removed in harvested roots from the fertilized plot $-\mathrm{N}$ removed in the check plot)/N applied]. Statistical analyses of the data were performed using PROC GLM,
At harvest (115 to $119 \mathrm{~d}$ after transplanting; linear and quadratic contrasts, and mean separation procedures outlined by SAS (SAS, 1990). Data were analyzed separately for each year with $\mathrm{N}$ rate and time of application as main factors. Optimum $\mathrm{N}$ rate for each application timing was determined by identifying the critical point (slope $=0$ ) for the regression model $f(x)$ $=\beta_{0}+\beta_{1} \mathrm{X}+\beta_{2} \mathrm{X}^{2}$.

\section{Results and Discussion}

Root yield response to $N$ rate. Nitrogen rate by time of application interactions were observed for the 2001 and 2002 yield data ( $p$ $<0.05$ ); thus analyses of yield response to $\mathrm{N}$ rate were performed at each level of application timing. Similarly, the effect of application timing was analyzed using mean separation procedures at each level of $\mathrm{N}$ rate. Although no interaction was present in 2000 , those data are also presented by $\mathrm{N}$ rate and application timing for consistency in reporting. Sweetpotato root yields increased as a result of $\mathrm{N}$ fertilization in each year of the study. Yield responses followed quadratic trends $(p<0.05)$ with optimum $\mathrm{N}$ rates ranging from 39 to $53 \mathrm{~kg} \cdot \mathrm{ha}^{-1}$ in 2000,36 to 63 in 2001 , and 19 to $40 \mathrm{~kg} \cdot \mathrm{ha}^{-1}$ in 2002 , depending on time of application (Table 3 ). The variation in optimum $\mathrm{N}$ rate over the course of the study appeared to be related to growing season precipitation. In 2000 , planting and early season conditions were normal; however, beginning shortly after the first sidedress $\mathrm{N}$ application and for the duration of the season, rainfall was about $64 \%$ greater than the 60-year average (Table 1). This weather pattern is reflected in the optimum $\mathrm{N}$ rate being lowest for preplant applications $\left(39 \mathrm{~kg} \cdot \mathrm{ha}^{-1}\right.$; Table 3) and increasing during the period of heavy rainfall to 50 and $53 \mathrm{~kg} \cdot \mathrm{ha}^{-1} 2$ to 3 and 4 to 5 WAT, respectively (Table 3 ). Although we have no substantiating data, it is possible that excessive rainfall could have resulted in some of the sidedress-applied $\mathrm{N}$ being leached out of the root zone. Our hypothesis that leaching of fertilizer $\mathrm{N}$ might have occurred in this study is supported by earlier work conducted at the same location that demonstrated greater sweetpotato yield responses to fertilizer $\mathrm{N}$ (higher optimum $\mathrm{N}$ rate) when growing season precipitation was excessive (60\% higher than average; Bellinder and Morse, 1982).

An apparent relationship between precipitation and optimum $\mathrm{N}$ rate was observed again in 2001. In 2001, rainfall in June was 58\% greater than normal (Table 1); however, most of the precipitation occurred before transplanting and only $38 \mathrm{~mm}$ was received during the first two weeks following transplanting. Rainfall remained moderate through the first sidedress tribution in the early to mid-growing season in 2001 resulted in optimum $\mathrm{N}$ rates being close to the optimum preplant rate in 2000 when precipitation was also normal (Table 3 ). However, during the first week following the second sidedress application, excessive rainfall was received (198 mm) and like 2000, the optimum $\mathrm{N}$ rate increased considerably (Table 3 ). No excessive rainfall events occurred in 2002 (Table 1); thus, optimum $\mathrm{N}$ rates were consistent across application timings and similar to those observed for applications made during periods of normal rainfall in previous years (Table 3). Further evidence for an $\mathrm{N}$ rate-rainfall relationship exists in the check (no $\mathrm{N}$ applied) yields for each year. Although initial soil inorganic $\mathrm{N}\left(\mathrm{NO}_{3}-\mathrm{N}+\mathrm{NH}_{4}-\mathrm{N}\right)$ levels $(0$ to $15 \mathrm{~cm})$ were not different in any year $\left(\sim 7.5 \mathrm{mg} \cdot \mathrm{kg}^{-1}\right.$; annual data not reported), in 2002, when precipitation was normal throughout the growing season, check yields were considerably higher than in the previous two years (Table 3), suggesting that available soil $\mathrm{N}$ at transplanting in 2000 and 2001 became unavailable at some point during the season.

Our data indicate that under typical conditions (times of normal, or average, precipitation), $\mathrm{N}$ at about $35 \mathrm{~kg} \cdot \mathrm{ha}^{-1}$ is adequate for optimum yield of 'Beauregard' sweetpotato. However, $\mathrm{N}$ at about $55 \mathrm{~kg} \cdot \mathrm{ha}^{-1}$ was required under excesapplication in July. The average rainfall dis-

Table 3. Marketable yield of 'Beauregard' sweetpotato roots following various $\mathrm{N}$ fertilizer rates and application timings, Painter, Va., 2000 through 2002.

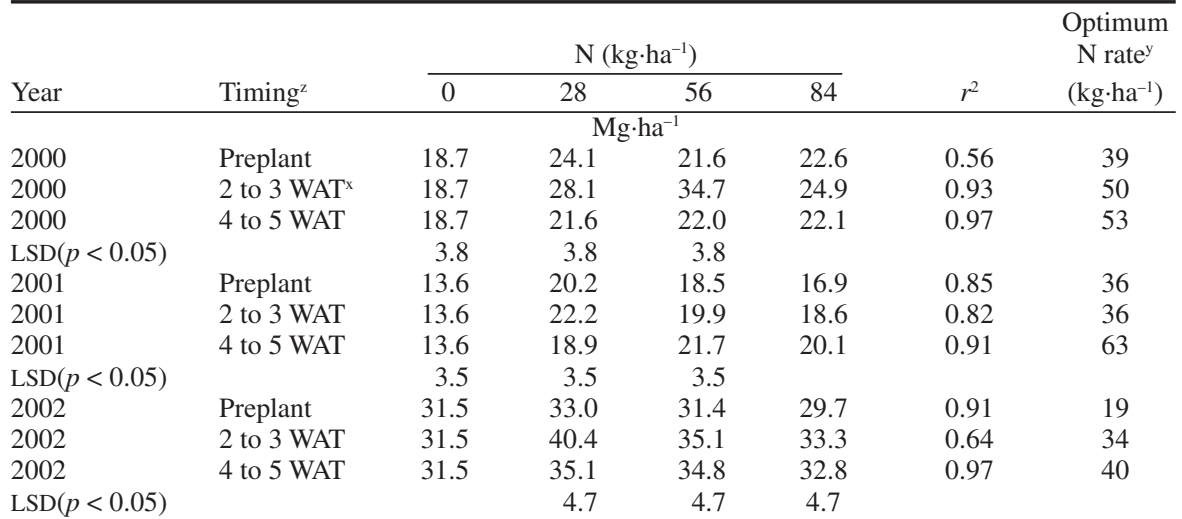

${ }^{2}$ Timing indicates time of $\mathrm{N}$ application; before transplanting (preplant), 2 to 3 WAT, or 4 to 5 WAT. ${ }^{y}$ Optimum $\mathrm{N}$ rate for each application timing was determined by identifying the critical point $($ slope $=0)$ for the regression model $\mathrm{f}(\mathrm{x})=\beta_{0}+\beta_{1} \mathrm{x}+\beta_{2} \mathrm{x}^{2}(p<0.05)$.

${ }^{\mathrm{x}} \mathrm{WAT}=$ weeks after transplanting. 
sively wet conditions (Tables 1 and 3). These results support the conclusions of Jester (1995) who reported that $\mathrm{N}$ at $56 \mathrm{~kg} \cdot \mathrm{ha}^{-1}$ was adequate for 'Beauregard' production in North Carolina, even under excessive precipitation that resulted in fertilizer leaching. Our data also confirm Jester's supposition that $\mathrm{N}$ rates lower than 56 $\mathrm{kg} \cdot \mathrm{ha}^{-1}$ can be used for commercial 'Beauregard' production (Jester, 1995). Mulkey et al. (1993) reported optimum $\mathrm{N}$ rates for 'Beauregard' production to be closer to $50 \mathrm{~kg} \cdot \mathrm{ha}^{-1}$ under typical growing conditions in Louisiana. However, they produced considerably higher yields than in our study or the North Carolina study; thus removing more $\mathrm{N}$ and subsequently increasing the $\mathrm{N}$ demand. Therefore, the $\mathrm{N}$ requirement under normal conditions in Louisiana would be expected to be higher than that in Virginia or North Carolina.

Root yield response to timing of $\mathrm{N}$ application. Delaying $\mathrm{N}$ application until 2 to 3 WAT significantly increased marketable root yields in 2000 and 2002 (Table 3). Timing of $\mathrm{N}$ application did not significantly affect root yield in 2001. The lack of response to timing of $\mathrm{N}$ applications in 2001 may be due to an overall

Table 4. USDA root grade distribution of 'Beauregard' sweetpotato as affected by $\mathrm{N} \mathrm{rate}{ }^{z}$ and application timing, Painter, Va., 2000 through 2002.

\begin{tabular}{|c|c|c|c|c|c|c|c|}
\hline \multirow[b]{2}{*}{ Year } & \multicolumn{3}{|c|}{$\begin{array}{l}\text { Weeks after transplanting } \\
{\left[\mathrm{N}\left(\mathrm{kg} \cdot \mathrm{ha}^{-1}\right)\right]}\end{array}$} & \multicolumn{4}{|c|}{$\operatorname{Grade}^{y}(\%)$} \\
\hline & 0 & 2 to 3 & 4 to 5 & US \#1 & Canner & Jumbo & Cull $^{x}$ \\
\hline \multirow[t]{3}{*}{2000} & 28 & 0 & 0 & 62 & 30 & 8 & 23 \\
\hline & 0 & 56 & 0 & 63 & 27 & 10 & 22 \\
\hline & 0 & 0 & 56 & 56 & 36 & 8 & 27 \\
\hline $\operatorname{LSD}(p<0.05)$ & & & & 7 & 5 & 4 & 4 \\
\hline \multirow[t]{3}{*}{2001} & 28 & 0 & 0 & 61 & 30 & 9 & 14 \\
\hline & 0 & 28 & 0 & 66 & 30 & 4 & 13 \\
\hline & 0 & 0 & 56 & 59 & 36 & 5 & 12 \\
\hline $\operatorname{LSD}(p<0.05)$ & & & & 7 & 6 & 6 & 3 \\
\hline \multirow[t]{3}{*}{2002} & 28 & 0 & 0 & 65 & 16 & 19 & 12 \\
\hline & 0 & 28 & 0 & 66 & 17 & 17 & 12 \\
\hline & 0 & 0 & 28 & 66 & 17 & 17 & 13 \\
\hline $\operatorname{LSD}(p<0.05)$ & & & & 7 & 4 & 7 & 2 \\
\hline
\end{tabular}

${ }^{2}$ Nitrogen rate reported is the rate resulting in the highest marketable root yield at a given application time.

${ }^{\mathrm{y}}$ Grade: USDA root grade: US \#1, diameter of $4.4 \leq 8.9 \mathrm{~cm}$; canner, diameter of $2.5 \leq 4.4 \mathrm{~cm}$; jumbo, diameter $>8.9 \mathrm{~cm}$; cull, malformed or distorted roots.

${ }^{\mathrm{x}} \mathrm{Cull}=$ reported percentages of culled roots represent the nonmarketable portion of the total harvest; US \#1, canner, and jumbo are expressed as percentages of marketable roots.

Table 5. Crude protein content, $\mathrm{N}$ uptake, and $\mathrm{N}$ use efficiency of 'Beauregard' sweetpotato roots as affected by various $\mathrm{N}$ rates and application timings, Painter, Va., 2000 to $2001 .^{\mathrm{z}}$

\begin{tabular}{|c|c|c|c|c|c|c|}
\hline \multirow[b]{2}{*}{$\begin{array}{l}\text { N rate } \\
\left(\mathrm{kg} \cdot \mathrm{ha}^{-1}\right)\end{array}$} & \multicolumn{3}{|c|}{2000} & \multicolumn{3}{|c|}{2001} \\
\hline & $\begin{array}{l}\text { Crude protein } \\
\left(\mathrm{g} \cdot \mathrm{kg}^{-1}\right)\end{array}$ & $\begin{array}{l}\text { N uptake } \\
\left(\mathrm{kg} \cdot \mathrm{ha}^{-1}\right)\end{array}$ & $\begin{array}{l}\mathrm{NUE}^{y} \\
(\%)\end{array}$ & $\begin{array}{l}\text { Crude protein } \\
\left(\mathrm{g} \cdot \mathrm{kg}^{-1}\right)\end{array}$ & $\begin{array}{l}\mathrm{N} \text { uptake } \\
\left(\mathrm{kg} \cdot \mathrm{ha}^{-1}\right)\end{array}$ & $\begin{array}{l}\text { NUE } \\
(\%)\end{array}$ \\
\hline 0 & 52.0 & 41.2 & ---- & 54.0 & 30.5 & --- \\
\hline 28 & 56.5 & 47.7 & 45.6 & 66.9 & 45.2 & 59.7 \\
\hline 56 & 59.2 & 50.8 & 27.3 & 67.9 & 45.0 & 26.4 \\
\hline \multirow[t]{2}{*}{84} & 68.2 & 54.2 & 20.5 & 77.5 & 50.1 & 23.6 \\
\hline & $\mathrm{L}^{* *}$ & $\mathrm{~L}^{* *}$ & $\mathrm{~L}^{* *}$ & $\mathrm{~L}^{* *}$ & L+ & $\mathrm{L}^{* *}$ \\
\hline $56^{\mathrm{x}}$ & 66.1 & 56.7 & 28.4 & 79.6 & 48.6 & 32.8 \\
\hline \multicolumn{7}{|c|}{ Time of application } \\
\hline Preplant & 59.7 & 42.5 & 19.4 & 70.9 & 42.9 & 18.9 \\
\hline 2 to 3 WAT $^{\mathrm{w}}$ & 59.5 & 55.0 & 33.7 & 71.9 & 48.8 & 41.6 \\
\hline 4 to 5 WAT & 64.4 & 54.1 & 35.0 & 69.8 & 48.4 & 34.6 \\
\hline $\operatorname{LSD}(p<0.05)$ & 6.6 & 10.5 & 11.3 & 7.3 & 10.9 & 15.1 \\
\hline
\end{tabular}

${ }^{2}$ Reported means are averaged across application times or rates unless indicated otherwise.

${ }^{\mathrm{y}} \mathrm{NUE}=$ nitrogen use efficiency; $[(\mathrm{N}$ removed in the fertilized plot $-\mathrm{N}$ removed in the check plot $) / \mathrm{N}$ applied].

${ }^{\mathrm{x}}$ Applied in two increments of $28 \mathrm{~kg} \cdot \mathrm{ha}^{-1}$ preplant and 2 to 3 weeks after transplanting.

${ }^{w} \mathrm{WAT}=$ weeks after transplanting.

${ }^{*}$ Significant at $p<0.01 ; \mathrm{L}=$ linear. when it is applied 2 to 3 WAT compared with the same rate applied earlier or later in the season. Splitting the $56-\mathrm{kg} \cdot \mathrm{ha}^{-1}$ rate into two $28-\mathrm{kg}$ increments did not increase marketable root yield in any year over a single application of $56-\mathrm{kg} \cdot \mathrm{ha}^{-1}$ 2 to 3 WAT (data not reported).

Root size distribution. Distributions of USDA root grades for each year of the study are reported in Table 4. Average size distribution for our 3-year study $(65 \%$ US \#1, 25\% canner, and $10 \%$ jumbo) was similar to distributions reported for 'Beauregard' studies conducted in Louisiana (Mulkey et al., 1993; Rolston et al., 1987) and North Carolina (Jester, 1995; Schultheis et al., 1999). The main effect of $\mathrm{N}$ timing significantly affected root size distribution in 2000 and 2001 (Table4). Delaying N application until 4 to 5 WAT reduced the percentage of US \#1 grade roots and increased the percentage of canner roots (Table 4). In 2000, the percentage of culled roots also increased when $\mathrm{N}$ application was delayed 4 to 5 WAT compared with $\mathrm{N}$ applications made preplant or 2 to 3 WAT (Table 4). An effect of $\mathrm{N}$ timing on root size distribution was also reported by Mulkey et al. (1993) who found that delaying $\mathrm{N}$ application beyond 4 WAT increased canners $35 \%$ and decreased jumbo roots $50 \%$. Conversely, Jester (1995) found no significant effect of N timing on root size distribution in North Carolina. It is noteworthy, however, that although the reported changes in root size distribution were not statistically significant, applying $\mathrm{N}$ at 5 WAT decreased the percentage of jumbo grade roots $78 \%$ compared to applying the same $\mathrm{N}$ rate 3 WAT (Jester, 1995). Jester (1995) and Mulkey et al. (1993) both reported N rate to have no effect on the relative size distribution of 'Beauregard' roots.

Researchers working with 'Jewel' sweetpotato similarly reported $\mathrm{N}$ rate to have no effect on root size distribution (Hammett et al., 1984). However, Constantin et al. (1984) found that increasing $\mathrm{N}$ rates from 0 to $50 \mathrm{~kg} \cdot \mathrm{ha}^{-1}$ linearly increased both total marketable yield and the percentage of US \#1 grade roots for the sweetpotato cv. Centennial and Goldrush. Nitrogen rates $>50 \mathrm{~kg} \cdot \mathrm{ha}^{-1}$ did not further increase yield or the percentage of US \#1 roots (Constantin et al., 1984), suggesting that the optimum $\mathrm{N}$ rate for total yield can also result in the most economically desirable size distribution [i.e., high percentage of US \#1 grade roots and a low percentage of canners and culls (Schultheis et al., 1999)]. Our data also demonstrated a relationship between optimum $\mathrm{N}$ rate and desirable size distributions. For example, in 2000, $\mathrm{N}$ applied preplant at 28 $\mathrm{kg} \cdot \mathrm{ha}^{-1}$ resulted in a root size distribution not different from that obtained when $56 \mathrm{~kg} \cdot \mathrm{ha}^{-1}$ was applied 2 to 3 WAT (Table 4). However, applying $56 \mathrm{~kg} \cdot \mathrm{ha}^{-1}$ preplant resulted in a lower percentage of US \#1 roots (54\%) and higher percentages of canners and culls (41 and 35\%, respectively). Similarly, when only $28 \mathrm{~kg} \cdot \mathrm{ha}^{-1}$ was applied 2 to 3 WAT, the result was fewer jumbo roots $(5 \%)$ and a higher percentage of canners $(33 \%)$. This finding was observed again in 2001 with excessive $\mathrm{N}\left(56 \mathrm{~kg} \cdot \mathrm{ha}^{-1}\right)$ applied 2 to 3 WAT resulting in a higher percentage of canners (39\%) and a lower percentage of US \#1 roots $(51 \%)$ compared with $28 \mathrm{~kg} \cdot \mathrm{ha}^{-1}$ applied at 
the same time. Splitting the $56-\mathrm{kg} \cdot \mathrm{ha}^{-1}$ rate into two $28-\mathrm{kg} \cdot \mathrm{ha}^{-1}$ increments did not affect root size distribution compared to a single application of $56 \mathrm{~kg} \cdot \mathrm{ha}^{-1}$ in any year (data not reported).

Root dry matter percentage, crude protein content, and N uptake. Root dry matter percentage was not affected by $\mathrm{N}$ rate or timing in any year of the study. Results from other studies have varied regarding the effect of $\mathrm{N}$ fertilizer on root dry matter percentage. Constantin et al. (1984) reported that dry matter content increased linearly (25.6\% to $26.3 \%$ ) with increasing $\mathrm{N}$ rates, while Hill et al. (1990) found no effect on root dry matter percentage following $\mathrm{N}$ additions. What is interesting about our results, is that while the effect of $\mathrm{N}$ rate on dry matter percentage was not statistically significant (similar to Hill et al., 1990), the increase in dry matter percentage with increasing increments of $\mathrm{N}(20.6 \%$ to $21.9 \%$ ) was greater than that observed by Constantin et al. (1984) where the relationship was determined to be significant.

Researchers have also cited linear increases in crude protein content with increasing $\mathrm{N}$ rates for several cultivars including 'Centennial', 'Jewel', and 'Goldrush' (Purcell et al., 1982; Constantin et al., 1984). Our results with 'Beauregard' support those from other studies in that crude protein content increased with increasing $\mathrm{N}$ rates up to $84 \mathrm{~kg} \cdot \mathrm{ha}^{-1}(p<0.01$; Table 5). Average crude protein levels for 'Beauregard' (Table 5) were similar to those reported for other cultivars evaluated in the earlier studies (Constantin et al., 1984; Purcell et al., 1982). Delaying $\mathrm{N}$ application 2 to 3 or 4 to 5 WAT did not affect crude protein levels compared to applying $\mathrm{N}$ before transplanting (Table 5). However, splitting the $56-\mathrm{kg} \cdot \mathrm{ha}^{-1}$ rate into two $28-\mathrm{kg}$ increments applied at transplanting and 2 to 3 WAT increased crude protein compared with a single $56-\mathrm{kg} \cdot \mathrm{ha}^{-1}$ application applied either before transplanting, 2 to 3 WAT, or 4 to 5 WAT in both 2000 and 2001 (Table 5).

Root Nuptake also increased with increasing $\mathrm{N}$ rate in 2000 and $2001(p<0.01$; Table 5). Timing of $\mathrm{N}$ application did not affect $\mathrm{N}$ uptake in 2001; however, in 2000, delaying $\mathrm{N}$ application 2 to 3 or 4 to 5 WAT increased $\mathrm{N}$ uptake compared with applying $\mathrm{N}$ before transplanting (Table 5). The occurrence of this response in 2000 and not in 2001 might be related to differences in rainfall patterns reported in Table 1 and discussed in previous sections. Hill et al. (1990) reported increased Nuptake in total biomass following $\mathrm{N}$ fertilization of six cultivars; however, only two out of the six cultivars had significantly higher N uptake levels in storage roots compared with nonfertilized plants. One point they found particularly noteworthy in their work was that as much as 42 and $86 \mathrm{~kg} \cdot \mathrm{ha}^{-1}$ was taken up in the unfertilized and fertilized plots, respectively (Hill et al., 1990). Mineralization of soil organic matter appears to be a reasonable explanation for these results; however, since their trials were conducted on soils with very low inorganic $\mathrm{N}$ and organic C levels ( $11 \mathrm{mg} \cdot \mathrm{kg}^{-1}$ and $7.5 \mathrm{~g} \cdot \mathrm{kg}^{-1}$, respectively), they concluded that indigenous or residual soil N levels were not solely responsible for the amounts of $\mathrm{N}$ uptake measured in the plots (Hill et al., 1990). Hill et al. (1990) cited several possible explanations for such results including enhanced fibrous root exploration, symbiotic $\mathrm{N}_{2}$ fixation, and other microbial $\mathrm{N}$ contributions, all of which can lead to certain genotypes being highly efficient in scavenging for scarce soil $\mathrm{N}$ reserves.

We observed $\mathrm{N}$ uptake responses similar to those reported by Hill et al. (1990) at the 0 and 28-kg.ha ${ }^{-1}$ rates in 2000 and 2001 (Table 5). In both years, root $\mathrm{N}$ uptake measured for the $0-\mathrm{N}$ plots was considerably higher than what would have been expected given the low levels of residual soil $\mathrm{N}\left(\sim 7.5 \mathrm{mg} \cdot \mathrm{kg}^{-1}\right)$ and the $28 \mathrm{~kg} \cdot \mathrm{ha}^{-1}$ rate resulted in $\mathrm{N}$ uptake levels greater than the sum of inorganic soil $\mathrm{N}$ and applied fertilizer $\mathrm{N}$ (Table 5). Although root $\mathrm{N}$ uptake continued to increase beyond $28 \mathrm{~kg} \cdot \mathrm{ha}^{-1}$, N uptake no longer equaled $\mathrm{N}$ applied at the higher rates (Table 5). Although unverified in our study, it is not unreasonable to conclude that 'Beauregard' may possess one or more of the attributes identified by Hill et al. (1990); thus partially explaining its lower fertilizer $\mathrm{N}$ requirement compared with other cultivars (Jester, 1994; Peet, 2003).

Nitrogen use efficiency. Nitrogen use efficiency of 'Beauregard' sweetpotato decreased with increasing $\mathrm{N}$ rate in 2000 and 2001 ( $p<$ 0.01 ; Table 5). Other researchers have calculated NUEdifferently, but the trends have been similar to those observed in our study (Marti and Mills, 2002; Villagarcia et al., 1998). A valid comparison of 'Beauregard' NUE with the cultivars used in the studies cited above is not possible due to different calculation methods; however, differences in NUE among cultivars have been cited. Villagarcia et al. (1998) noted that under nonlimiting N supplies, the NUE of MD810 and 'Jewel' were not different but under N-limiting conditions, the NUE of MD810 was almost twice that of 'Jewel'. Hill et al. (1990) did not evaluate NUE in their work; however, they reported all of the data necessary to calculate NUE using the method employed in our study.

Our calculated NUE values for the six cultivars evaluated by Hill et al. (1990) ranged from $20 \%$ to $88 \%$. The cultivars with the highest $\mathrm{N}$ uptake levels relative to $\mathrm{N}$ applied (mostefficient scavengers) had an average NUE of 55\%. The NUE for the less efficient cultivars averaged $29 \%$. In our dataset, only the $28-\mathrm{kg} \cdot \mathrm{ha}^{-1}$ rate had $\mathrm{N}$ uptake levels that exceeded the soil-N and fertilizer- $\mathrm{N}$ contributions (Table 5). If we group our $\mathrm{N}$-rate treatments in a categorically similar manner as the cultivars of Hill et al. (1990), we would identify 'Beauregard' as a highly efficient scavenger of $\mathrm{N}$ at low fertility levels (NUE of $53 \%$ at the $28-\mathrm{kg} \cdot \mathrm{ha}^{-1}$ rate) and much less efficient at higher $\mathrm{N}$ fertility levels (NUE of $24 \%$ at $\mathrm{N}$ rates $>28 \mathrm{~kg} \cdot \mathrm{ha}^{-1}$ ).

Splitting the N into two applications did not affect NUE in either year; however, delaying a single $\mathrm{N}$ application 2 to 3 or 4 to 5 WAT significantly increased NUE compared with a preplant application (Table 5). Because there were no significant interactions present in the NUE analyses, data were not reported by rate and timing. Nonetheless, if we consider our most efficient $\mathrm{N}$ rate $\left(28 \mathrm{~kg} \cdot \mathrm{ha}^{-1}\right)$ applied at the most efficient time ( 2 to 3 WAT); the NUE values for 'Beauregard' in 2000 and 2001 were 59\% and $75 \%$, respectively.

Our work clearly establishes that 'Beaure- gard' is more productive (Table 3) and more efficient (Table 5) at $\mathrm{N}$ rates considerably lower than those currently recommended for Virginia sweetpotato production(Alexanderetal., 2003). Applying the appropriate $\mathrm{N}$ rate $\left(\sim 35 \mathrm{~kg} \cdot \mathrm{ha}^{-1}\right)$ 2 to 3 WAT maximized root yield, percentage of US \#1 grade roots, and NUE.

\section{Literature Cited}

Alexander, S.A., A.D. Bratsch, H.E. Hohlt, T.P. Kuhar, S.B. Phillips, S.B. Sterrett, and H.P. Wilson. 2003. Commercial vegetable production recommendations. Va. Coop. Ext. Publ. 456-420.

Bellinder, R. and R. Morse. 1982. Effect of nitrogen and precipitation on yield of sweetpotato. Veg. Growers News. 36(10). Va. Tech, Blacksburg, Va.

Constantin, R.J., T.P. Hernandez, and L.G. Jones. 1974. Effects of irrigation and nitrogen fertilization on quality of sweetpotatoes. J. Amer. Soc. Hort. Sci. 99:308-310.

Constantin, R.J., L.G. Jones, H.L. Hammett, T.P. Hernandez, and C.G. Kahlich. 1984. The response of three sweetpotato cultivars to varying levels of nitrogen. J. Amer. Soc. Hort. Sci. 109(5):610-614

Hammett, L.K., C.H. Miller, W.H. Swallow, and C. Harden. 1984. Influence of $\mathrm{N}$ source, $\mathrm{N}$ rate, and $\mathrm{K}$ rate on the yield and mineral concentration of sweet potato. J.Amer. Soc. Hort. Sci. 109(3):294-298.

Hill, W.A., H. Dodo, S.K. Hahn, K. Mulongoy, and S.O. Adeyeye. 1990. Sweet potato root and biomass production with and without nitrogen fertilizer. Agron. J. 82:1120-1122.

Jester, W.R. 1995. Cultural practices for maximizing 'Beauregard' sweet potato yield and quality. Agent Update Nwsltt. 7(2):6-9. Univ. Md., Wye Research and Education Center, Queenstown.

Marti, H.R. and H.A. Mills. 2002. Nitrogen and potassium nutrition affect yield, dry weight partitioning, and nutrient use efficiency of sweet potato. Commun. Soil Sci. Plant Anal. 33:287-301.

Mascianica, M.P., R.R. Bellinder, B. Graves, R.D. Morse, and H. Talleyrand. 1985. Forecasting of $\mathrm{N}$ fertilizer requirements for sweet potatoes. J. Amer. Soc. Hort. Sci. 110(3):358-361.

Mulkey, W.A., W.B. McLemore, and T.P. Talbot. 1993. Sweet potato nitrogen fertility research 1992-1993. Sweet Potato Res. Sta. Rpt., Chase, La.

Peet, M. 2003. Sustainable practices for vegetable production in the south. 27 Feb. 2003. http://www.cals.ncsu. edu/sustainable/peet/profiles/pps_pot.html.

Purcell, A.E., W.M. Walter, Jr., and F.G. Giesbrecht. 1978. Root, hill and field variance in protein content of North Carolina sweet potatoes. J. Agr. Food Chem. 26:362-364

Purcell, A.E., W.M. Walter, Jr., J.J. Nicholaides, W.W. Collins, and H. Chancy. 1982. Nitrogen, potassium, sulfur fertilization, and protein content of sweet potato roots. J. Amer. Soc. Hort. Sci. 107(3):425-427.

Rolston, L.H., C.A. Clark, J.M. Cannon, W.M. Randle, E.G. Riley, P.W. Wilson, and M.L. Robbins. 1987. 'Beauregard' sweet potato. HortScience 22(6):1338-1339.

Statistical Analysis System Institute. 1990. SAS/STAT user's guide. release 6.03 ed. SAS, Cary, N.C.

Schultheis, J.R., S.A. Walters, D.E. Adams, and E.A. Estes. 1999. In-row plant spacing and date of harvest of 'Beauregard' sweetpotato affect yield and return on investment. HortScience 34(7): 1229-1233.

Tuckey, D.M. 2001. Crop profile for sweetpotatoes in Virginia. 27 Feb. 2003. http://pestdata.ncsu.edu/cropprofiles/docs/vasweetpotato.html.

U.S. Dept. of Agriculture. 1981. United States standards for grades of sweetpotatoes. U.S. Dept. Agr. Mktg. Serv., Wash., D.C.

Villagarcia, M.R., W.W. Collins, and C.D. Raper, Jr. 1998. Nitrate uptake and nitrogen use efficiency of two sweetpotato genotypes during early stages of storage root formation. J. Amer. Soc. Hort. Sci. 123(5):814-820.

Virginia Agricultural Statistics Service. 2002. Agricultural statistics bulletin and resource directory. No. 77. Va. Dept. of Agr. Consumer Serv., Richmond, Va.

Walker, D.W. and W.R. Woodson. 1987. Nitrogen rate and cultivar effects on nitrogen and nitrate concentration of sweet potato leaf tissue. Commun. Soil Sci. Plant Anal. 18(5):529-541. 